Article

\title{
Four Thinkers in the Twentieth Century Genealogy of Mexicanidad: Justo Sierra, Samuel Ramos, José Vasconcelos, and Octavio Paz
}

\author{
John Kaiser Ortiz \\ Department of Philosophy, Millersville University, Millersville, PA 17551, USA; john.kaiserortiz@millersville.edu \\ Received: 29 March 2020; Accepted: 11 June 2020; Published: 9 July 2020 \\ check for \\ updates
}

\begin{abstract}
The twentieth-century development of Mexicanidad underwent a series of treatments that changed how selfhood in Mexico was problematized and understood. Octavio Paz's claim that Mexicanidad faced historical and philosophical obstacles in its development, such as the problem of solitude, allowed him to go beyond the accounts of Mexicanidad provided by Justo Sierra, José Vasconcelos, and Samuel Ramos. Paz's account of Mexicanidad sought an explicit connection between the Mexican experience of solitude and the universal human experience of solitude. This paper demonstrates how Paz's revised account addresses these and other problems in twentieth-century Latin American quests for national identity.
\end{abstract}

Keywords: Mexicanidad; lo Mexicano; modernity; solitude; Justo Sierra; Samuel Ramos; José Vasconcelos; Octavio Paz

\section{Introduction}

In his essay "The History of Philosophy in Mexico" (1943), Samuel Ramos claims that "it has always seemed to me that one of the ways of doing Mexican philosophy is to reflect on our own philosophical reality, the reality of Mexican philosophers and their ideas, to find out if there are dominant features that characterize a national mind" (Ramos 2017, p. 64). Ramos's search has been instructive for ensuing generations of scholars who, by the late twentieth and early twenty-first century, have furthered and continue to advance the project of inquiring into the origins and nature of a distinctly Mexican way of thinking and being. What counts as fundamental or foundational in Mexican philosophical studies, then as now, is tethered to two pillars of thought: lo Mexicano and Mexicanidad. Lo Mexicano is defined as all that is authentically Mexican; lo Mexicano encompasses all that is born of, expressed in, or represented through Mexican cultural practice. Mexicanidad concerns bona fide or genuine Mexican national identity or national character; Mexicanidad may also glossed as Mexican national (or social) consciousness. Mexicanidad and lo Mexicano both raise questions about selfhood, especially the authentic self or character. Questions of Mexicanidad are the central philosophical problem of Mexican philosophers in the twentieth century.

Ramos, of course, was not twentieth-century Mexico's only philosophical investigator. Nevertheless, a spate of recent translations and publications in Mexican (and increasingly Mexican-American and/or Chicana/o/x philosophy) show that Ramos stood among a vast and growing group of thinkers who were similarly dedicated to theoretical pursuits (Sánchez and Sanchez 2017; Pitts et al. 2020). In fact, current scholarship has reintroduced an entirely fresh cast of Mexican philosophical actors onto the scene. Figures like Elsa Frost, José Gaos, Alfonso Reyes, Emilio Uranga, Abelardo Villegas, Luis Villoro, and certainly the four thinkers addressed here-most of whom were sorely absent from philosophical journal representation in recent decades-have roused contemporary scholarly attention. Indeed, the ascendency and popularization of Latin American philosophy in general and Mexican thought in 
particular have given way to a vast and growing body of emergent and exciting philosophical studies in the first two decades of this century.

Scholarship on twentieth-century Mexican philosophy has seen at least two emergent narratives or tendencies. Whereas earlier attempts, at the close of the last century and the opening of this one, at tracing the origins and development of Mexicanidad inquired into national identity against the general question "what is Latin American philosophy?", today's next-generation approach seems to involve both a return to Spanish language originals and to improvised and strategic alliances between figures across multiple philosophical orientations and traditions (See Romanell 1967; Gracia 1986; Paz 1995a; Mendieta 2003; Sanchez 2014; Sánchez and Sanchez 2017). The connections between Latin American Philosophy and American Pragmatism in particular have, over the last two decades, seen a surge in interest. The need for a genealogical account of Mexicanidad that at once shows just how distinctive Mexican thought can be, while not isolating Mexican thought from other affiliated figures and traditions, is perhaps most pressing today, a century after the possibilities for a truly Mexican identity initially surfaced, and when the Latin American diaspora in the United States and throughout the world is seeing more public awareness and coverage than before. That such an account would engage more than two or three interlocutors in that tradition may be possible only now, from the vantage of a century-long emergence. (See Trejo-Villalobos 2018 for a valuable exception to the two or three author rule). This essay is an attempt at providing such a genealogical portrait of Mexican philosophy.

Four generations of thinkers are represented in this essay. The four figures chosen for this essay show an unswerving focus on national and personal identity as philosophical problems, including the cultural as well as national representations tied to their ideas and practices. Their grouping marks a fifth-generation (Sierra the first generation; Vasconcelos second; Ramos third; and Paz the fourth) attempt at putting emergent and established canonical figures and voices in dialogue. What makes these four views of Mexicanidad significant, then, is that their elemental and discursive contributions can be seen to have helped give a genealogical voice to a distinct twentieth-century philosophical tradition. Mexican philosophy is not only possible, but answerable, real, and unique. Going further, Mexican philosophy implies dynamism, meaning it generates arguments and differences within it. Moreover, the genealogical emergence of this tradition shows that ideas are generational and responsive to questions of human identity that are rooted in place and culture.

Importantly, each figure grappled intellectually with the aftermath of the Mexican Revolution. Writing about Paz (in connection with Uranga and Leopoldo Zea) in this regard, one scholar observes that "All three thinkers appear dissatisfied with the way in which the legacy of the revolution was distorted by post-revolutionary re-thinkings and are troubled by the ideological substratum of lo Mexicano" (Sánchez 2016, p. 3). The same could be said for Sierra, Vasconcelos, Ramos (not to mention Paz), all of whom remained dedicated to the cultivation, development, and education of moral character as a national priority-and yet, all four figures would agree that the cultivation of Mexican selfhood was a cultural necessity and philosophical priority. The Revolution, then, might be thought of as having induced the desire for all Mexicans to find themselves in each other, identity as community in a collective-driven pursuit of belonging, which is in part an escape from the feeling of solitude our lives produce. Thus, a generation after Ramos, Paz would claim "If the history of Mexico is that of a people seeking a form that will express them", then, "the history of the individual Mexican is that of a man aspiring to communion" (Paz 1985, p. 134). For Paz, the late nineteenth and early twentieth-century period was beset by a crisis in Mexican thought, one tied to the national (and hemispheric) thirst for a form of national identity (national character) that could address multiple experiences of solitude, viz., in its historical, national, and also personal forms.

I argue that Paz's critical engagement with the ideas and figures in this essay marks both the founding of an emergent philosophical practice and the formal continuance of a distinct genealogical tradition, both of which centered on questions of what it means to be Mexican. More specifically, Paz goes beyond what these three forebearers in particular (Sierra, Vasconcelos, and Ramos) argued were genuine forms of Mexican identity to construct a multi-dimensional account of Mexican selfhood. 
This movement is multi-generational and multi-purpose, too. Paz not only reverses the direction of thinking on the origins of Mexicanidad away from the racialized, political, biological, and psychological explanations of national identity given by Sierra, Vasconcelos, and Ramos to focus on its migratory nature and trans-Atlantic movement, but in locating his discussion of Mexicanidad outside of Mexico (at least in part), Paz boldly confronts European and North American countries whose influence on ideas had historically overshadowed the unique productions of Mexican and Latin American thinkers concerned with theorizing selfhood in terms of national identity.

Stated differently, my argument is that Paz predominates where Sierra, Vasconcelos, and Ramos lagged by explaining Mexican selfhood in terms of its trans-Atlantic and universal significance and not on its politically historicized, racialized, or psychologically inherited origins. Distancing himself especially from Vasconcelos and Ramos, Paz's account of Mexicanidad begins outside the national boundaries of Mexico in cosmopolitan Los Angeles. The fact that The Labyrinth of Solitude deals with Mexicanidad outside the national territories of Mexico suggests that Paz's is quite literally beyond the physical/spiritual graves and limitations of his predecessors. Paz is more than simply outside the box of his compatriots for he constructs an entirely different paradigm (or prison, cage) to characterize the metaphorical incarceration of Mexicanidad. Paz's notion of labyrinthine solitude suggests that the quest for Mexican identity is something closer to the experience embodied by such terms: we are, all of us, facing both our own history and the history of others human beings under similar (universal) conditions of solitude. Each new experience of solitude only propels human beings further down the maze (the labyrinth), and we have not yet discovered how to get out of this incarcerated search for identity that surrounds us and imprisons us from all sides. Paz concludes with the claim that the problem and so the experience of solitude is a universal characteristic of all human beings. Our search continues headlong, deeper into the labyrinth.

Paz redefines the historical and philosophical inheritance of questions pertaining to Mexicanidad in two important ways. First, he de-nationalizes and so transcends the hyper-nationalistic, geographically exclusive, politically restricted articulations of his predecessors. Second, in universalizing his account of the problem of solitude, Paz's conception of Mexican-turned-universal identity synthesizes the views of his predecessors in a manner that finds or locates, in all human beings, decidedly Mexican metaphysical, moral, and cultural attributes. In other words, Paz renders philosophical questions associated with Mexicanidad as distinct universal phenomena, not as merely as questions Mexicans who live in Mexico ask themselves. For Paz, the longing for love or communion, which is as much as a Mexican as a Mexican American or North American or (non) European response to the problem of solitude, gives selfhood the promise of purpose. Thus, in de-nationalizing/universalizing earlier generation accounts of Mexicanidad given by his forebearers in favor of those characteristics common to all human beings, Paz's genealogical treatment of Mexicanidad becomes, at the very same time, an account of universal human identity. This paper thus endeavors to demonstrate how Paz generates a genealogical account of Mexicanidad towards a view of the experience of solitude as both a Mexican and universal phenomenon.

This essay is organized into four sections. In parts one, two, and three, respectively, I examine the accounts of Mexicanidad furnished by Sierra, Vasconcelos, and Ramos. Part four outlines Paz's argument using the terms generated by his predecessors in each of the prior sections. The two principal works I use to explain Paz's account of Mexicanidad (which, as I will argue later, is also his account of universal human identity) are The Labyrinth of Solitude (published in Spanish in 1950) and The Double Flame (published in Spanish in 1993).

\section{Justo Sierra}

Justo Sierra was a political theorist whose writings augured the nascent theorization of Mexicanidad. In The Political Evolution of the Mexican People (1900-1902), Sierra maintains that the moral qualities of strength and vigor lie beneath the historical evolution of Mexican culture and that these qualities constitute a distinctly national (Mexican) form of selfhood. For Sierra, the evolution of Mexicanidad is 
but one product of the process of history, but this evolution requires political stewardship in order to vouchsafe what he argues is the inevitability of a distinctly Mexican form of national identity. Although Sierra's view is consistent with the age in which it was written-it appeared less than a decade before the Revolution of 1910 — he was not alone in his endeavors.

Sierra's political philosophy, particularly his development of Mexicanidad, can be seen as the expression of what the Ateneo de la Juventud achieved. The Ateneo de la Juventud, or Athenaeum of Youth, was a revolutionary-era group of intellectuals committed to critical reevaluations of what it meant to be a Mexican in both the popular and philosophical senses of the term. According to James D. Cockcroft, "The Ateneo, which met regularly in Mexico City, consisted of students, writers, artists, professionals, and teachers committed to free intellectual inquiry and a search for new intellectual concepts to replace the 'scientism' and 'dogmatism' of Positivism" (Cockcroft 1968, p. 58). Lending authority and fame to the Ateneo, besides Sierra were figures such as José Vasconcelos, Antonio Caso, and the young muralist Diego Rivera. Members of the Ateneo were fundamentally at odds with the predominant modes of thinking in Mexico whose artificial and disingenuous articulation, they claimed, invariably pointed to Positivism, the latest instance in ideas of European origin dominating native productions. Leopoldo Zea insists that "it was not so much positivism but the expression of positivism that was attacked" (Zea 1974, pp. 15-16). As far as the members of the Ateneo were concerned, positivism was the justification ruling elites used to enforce the introduction of ideas of European origin over those produced in Mexico. Positivism in particular, and European modes of thinking in general, were a bane under whose suffocating grip the Mexican self-struggled to be free.

According to Ramos, who was himself initiating a genealogical inquiry into Mexicanidad, "The cultural mission of the 'Athenaeum of Youth,' which began in 1908, should be interpreted as a struggle against the demoralization produced by the Porfirian era. This revolutionary intellectual movement preceded the political revolution that broke out two years later" (Ramos 1962, p. 86). Positivism metastasized into a social and political cancer for members of the Ateneo, but its initial appeal was not unlike infatuation or obsessive desire among these nationalist thinkers. Ramos observes that "however regrettable the consequences of positivism may ultimately have been for [Mexican] culture, the doctrine was at one point an element of liberation and progress for the minority in power ... Positivism won quick popularity, and its success was due to the fact that it answered a spiritual and social need in Mexico" (Ramos 1962, pp. 85-86). Patrick Romanell aptly described the scene in his The Making of the Mexican Mind (1952). Maintaining that "Positivism and Porfirism were like Siamese twins, and the fate of the one followed as the night the day that of the other", Romanell stressed that the Mexican Revolution signifies "a discovery of Mexico by Mexicans as well as a recovery of Mexico for Mexicans" (Ramos 1962, pp. 61-63). The emergence of Mexicanidad, in other words, signals the birth of a nation's consciousness along with that of its people's.

Sierra's work attempts to expose the spell of European ideas over the Mexican mind, a task pursued not without considerable opprobrium. Speaking of Mexicans during the years of the French Intervention (1861-1867), Sierra writes, “Educated Mexicans knew the history of France a hundred times better than they knew that of their own land" (Sierra 1969, p. 304). Sierra's antipathy towards positivism can be seen as an extension of his attitude towards the Spanish Conquest, which marked the beginning of a long history of European dominance over Latin America. The fact that Mexico experienced centuries of colonial rule before the nineteenth century, when three different nations took turns determining life and thought in Mexico, would seem to be a fact that influenced the development of national character studies in formidable ways.

Central to Sierra's account is the claim that the borders and boundaries of Mexico are an evolutionary planet's choice for the preferred site of emergence for both Mexican national identity and universal human identity. The relationship between selfhood and circumstances (or between nationality and identity) therefore suggests that place plays a key role in the formulation of authentic national character. This notion of place, as I use it in this paper, involves not just a fixed geographical 
setting, but also the historical context in which such ideas emerge. More to the point, the notion of place underscores the ways in which geography (location) and history (experience) bear on national identity.

Paz claimed that Sierra's work was a critical moment in the annals of Mexican (and Latin American) national character studies (Paz 1985, pp. 134-35). One problem with Sierra's view of Mexican national character development, however, is that he sees Mexicanidad in almost exclusively racialized and politicized terms. This challenge can be framed as the following question: granted that Mexico achieved liberty from Spain, the United States, and then France in the eighteenth century, what, then, hinders the development of an authentic national identity in the early twentieth century, according to Sierra? Insofar as I understand his position, Sierra would likely reply that positivism was the form of incarceration that hindered the achievement and flourishing of Mexicanidad. Political development, in other words, is but one area of growth required for the achievement of an authentic form of national identity. Moral development is another requirement.

In a recently translated speech given at the National University Inauguration of 1910, Sierra extols the social value of educators and forges a direct link between (moral or personal) character and national purpose. The strength, or will, of one's moral character is the proof of the resilience of Mexican spirit. Sierra writes, "Because to be strong, let us be clear, is to condense one's entire development-physical, intellectual, ethical, and aesthetic-into the formation of character" (Sierra 2017, p. 18). While the aesthetic dimensions of Vasconcelos's la raza cósmica have been duly raised, Sierra's claim in the foregoing passage shows that aesthetic considerations appear to be a central, if not constitutive feature of Mexican philosophic thought and practice. Sierra's contributions to the theorization of Mexicanidad, then, invest ideas and ideals of moral/social growth in education and the articulation of what Sierra, in the same speech, calls "Mexicanizing knowledge" (Sierra 2017, p. 18).

Sierra's influence over Vasconcelos, Ramos, and Paz is significant in two ways. First, Sierra was an early proponent of a uniquely Mexican form of identity that conceived of Mexicanidad not just in terms of selfhood and circumstances, but also in terms of other formative relationships, more generally speaking, that obtain between (non)citizens, colonial subjects/rulers, and the self and others. Second, Sierra found redemptive potential for Mexicanidad across a vast range of historical (and political) experiences. When seen in terms of his influence on the historical and philosophical development of Mexicanidad, Sierra's engagement with the legacy of a racialized conception of selfhood would clearly influence those inheriting this discussion. What, then, fundamentally constitutes Mexican selfhood? Sierra's reply to this question gives shape to a skeletal form of identity that is founded in and born of the dust, ashes, and blood of centuries of conquest leading up to the Mexican Revolution. A contemporary of such figures as the Argentinian José Enrique Rodó who was similarly concerned with national identity and authentic selfhood, Sierra's work set in motion the initial terms according under which Mexicanidad was burgeoning. Through Sierra, Mexican national consciousness registered a philosophical quickening in the range of its voice and the tenor of its purpose.

The next section examines the work of José Vasconcelos. Like Sierra, Vasconcelos' sees Mexicanidad as a unique product of the process of history itself, i.e., in terms of the social and political changes that had defined life in Mexico from the European Conquest up to and beyond the Mexican Revolution. Still, though both Sierra and Vasconcelos emphasized a racialized conception of Mexican selfhood, Vasconcelos would take the discussion of what it means to be a real Mexican in a decidedly different direction.

\section{José Vasconcelos}

Cosmopolitan sentiment in Mexico is, in many ways, indebted to educator and aesthetician José Vasconcelos, the self-named "Ulisses criollo", and his role in the theorization of Mexicanidad is not easily summarized. Vasconcelos' Cosmic Race earns its reputation as one of the earliest philosophical treatises on mestizaje, even though Vasconcelos had been concerned with questions of race, democracy, and Mexican identity at least since the mid-1920s (See Vasconcelos 1926). Mestizaje is the claim that personal identity is a biological product made possible by the historical process of racial mixing. 
Whereas Sierra characterized Mexicanidad as a political achievement produced by the process of history, Vasconcelos contends that the origins of true selfhood are accomplished through that racial admixture which leads to biological reproduction. Vasconcelos proposes that "present world conditions favor the development of interracial sexual unions, a fact which lends unexpected support to the thesis which, for lack of a better name, I entitled: the future Cosmic Race" (Vasconcelos 1997, p. 3). According to Vasconcelos, the historical evolution of Mexican social and political life indicated that it could serve as a model for a larger historical process of miscegenation —-that is, racial intermingling, racial mixing, or racial blending (Mignolo 2005, p. 133) - that would give rise to the final evolution of human existence, a fifth race, the cosmic race. This process of racial fusion or racial harmonization was well under way by the time Vasconcelos published his articulation of Mexicanidad.

Vasconcelos introduces this argument in part one of The Cosmic Race, "Mestizaje", where he suggests that scientific history and empirical history are, when taken separately, inadequate for "those who insist in looking for a plan in History" (Vasconcelos 1997, p. 8). He takes this idea further by claiming that "only a leap of the spirit, nourished with facts, can give us a vision that will lift us above the micro-ideology of the specialist" (Vasconcelos 1997, p. 8). Like his cohort of thinkers who were duly concerned with questions of national character, Vasconcelos recognizes the formative role of history and historical experience in shaping selves and civilizations. He writes, "Civilization ... always derives from a long, secular preparation and purification of elements that are transmitted and combined from the beginning of History" (Vasconcelos 1997, p. 11). Although Vasconcelos is concerned with the origins and historical growth of national identity, he introduces the novel idea, lacking in Sierra, that the process of history from which Mexicanidad is produced is the same process that leads to universal human identity. Hence, "the present state of civilization still imposes patriotism on us as a necessity for the defense of material and moral interests; but it is indispensable for this patriotism to seek vast and transcendental aims" (Vasconcelos 1997, p. 12).

Vasconcelos, in fact, maintains that if Mexicanidad is to be a framework for questions of selfhood, then Mexicanidad, in order to be truly authentic, must seek a form of selfhood compatible with universal human identity. A viable account of human experience binding Mexicanidad to universal human identity therefore must begin from some place within the territorial boundaries of Mexico. In this sense, mestizaje is for Vasconcelos is a universal, historically engaged social ideal, but one that is located in Mexico, a connection made evident when he writes, "The period in which the pyramids were built, and the Egyptian civilization reached its summit, is a mestizo period" (Vasconcelos 1997, p. 4). Going further, "the most illustrious epochs of humanity have been precisely those in which several different peoples have come into contact and mixed with each other" (Vasconcelos 1997, p. 32). However, "Our patriotism", writes Vasconcelos, "if we do not root it in Cuahtemoc and Atahualpa, it will have no support" (Vasconcelos 1997, p. 11). Vasconcelos adds, "even the most contradictory racial mixtures can have beneficial results, as long as the spiritual factor contributes to raise them" (Vasconcelos 1997, p. 5). The spiritual factor serves as the fulcrum upon which is balanced Vasconcelos' theory of Mexicanidad. Vasconcelos thus sees the future of Mexicanidad as "universal historical destiny" (Vasconcelos 1997, p. 12) but the form Mexican identity assumes must take into account both the place Mexico inhabits and the process of history itself. If the destination is cosmic selfhood, then the departure point is from some place within Mexico's borders.

The process characteristics Vasconcelos attributes to mestizaje requires a principle or promise of growth (transcendence). Vasconcelos balances two essential processes required for the origins and the growth of a cosmic race. The first process, as I have already indicated, is mestizaje, a historical process of racial mixing that physically (biologically) produces a cosmic race. The second process at work in Vasconcelos' essay is what can be called sincretismo. Sincretismo represents a method of (historical) understanding that harmonizes any of the given extremes characterizing the lived experience of human beings.

Mestizaje and sincretismo are related in at least one fundamental way; both are processes that result from the mixture of at least two opposite extremes (tenets, dispositions, beliefs, practices, ideals, 
etc.). Since mestizaje is the process of mixing or harmonizing different races within the same species of human being, then sincretismo comes to represent the process of mixing or harmonizing the historical extremes experienced by these same persons. Furthermore, mestizaje is a process of racial blending that happens on the level of biological reproduction. Sincretismo, in contrast, can apply to an individual's private sense of self as well as the sense any given generation has about its role in history. Mestizaje is the historical product of racial mixing; sincretismo is the historical process that allows such experiences as racial mixing to occur. What I am calling the principle of transcendence in the work of Vasconcelos can be seen as the mixing or blending of his accounts of mestizaje and sincretismo.

Vasconcelos bridges his accounts of mestizaje and sincretismo through a historical and biological conception of love. This subaltern conception of love is, on the one hand, a method of history. On the other, this conception is the product of what generations do to bring about the development of identity experienced at the level of universal human identity. For Vasconcelos, personal identity, national identity, and universal human identity are different stages on the path towards cosmic selfhood; all of these stages or forms of identity as brought about through processes of historical growth. In consequence, a relationship appears to be unfolding in the historical development of Mexicanidad that sees human identity as one product of selfhood and circumstances. Place thus reemerges in the work of Vasconcelos as a familiar marker along the path towards Mexican identity and universal human identity.

Paz comments on Vasconcelos' ideal in The Labyrinth of Solitude. He writes, "If the Revolution was a search and an immersion of ourselves in our origins and being", then "no one embodied this fertile, desperate desire better than José Vasconcelos, the founder of modern education in Mexico" (Paz 1985, p. 152). Paz adds, "Vasconcelos, as a philosopher and a man of action, possessed that unity of vision which brings coherence to diverse plans, and although he sometimes overlooked details, he never lost himself in them" (Paz 1985, p. 152). Paz praises Vasconcelos for his attempts at secularizing Mexican discourse and universalizing Mexican experience, but he clearly prefers the account of Mexicanidad developed by Ramos to that of Vasconcelos.

\section{Samuel Ramos}

Samuel Ramos furthers the historical and philosophical development of Mexican national character begun by Sierra and Vasconcelos. Ramos credits Sierra for viewing "historical evolution as a great progressive movement that leads to the achievement of freedom" (Ramos 1962, p. 165). Ramos adds, "Freedom in the broadest sense is the ideal to which the Mexican people should aspire as the final goal of their social evolution" (Ramos 1962, p. 165). Ramos marks an important shift in the historical and philosophical development of Mexicanidad in the sense that, for the first time, racialized accounts of Mexicanidad are jettisoned in favor a psychological explanation. The account of Mexicanidad Ramos seeks can be seen as a movement away from a discussion of social and political possibilities towards the psychological realities underwriting Mexican selfhood. Accordingly, only a psychological framework can expose those attitudes, beliefs, and dispositions that seemed to prevent the historical and moral realization of a truly authentic Mexican national identity. With Ramos, it is as if the birth and early development of Mexicanidad in Sierra and Vasconcelos grew to face the troubled years of psychological introspection and struggle that characterize adolescence.

Ramos explains his intentions for Profile of Man and Culture in Mexico (1934) as his "ambition to establish a theory which would explain the real character of Mexican man and his culture", (Ramos 1962, p. 4). In this work, Ramos argues that an inferiority complex defines and restrains Mexican ideas on the meaning and value of national character. Ramos's thesis claims "that some expressions of Mexican character are ways of compensating for an unconscious sense of inferiority" (Ramos 1962, p. 9). Ramos is not suggesting that Mexicans were, in fact, inferior beings. Rather, Ramos seeks to show how Mexicans suffered from a feeling of inferiority to such a degree that they could be described as having internalized a complex that prevented their flourishing and development. 
Ramos emphasizes this distinction: "It is not that the Mexican is inferior, but that he feels inferior" (Ramos 1962, p. 57).

Ramos's exemplar for illustrating the Mexican self is the pelado, "for he constitutes the most elemental and clearly defined expression of national character". (Ramos 1962, p. 58). The pelado "is the kind of person who continually lays bare his soul, so that its most intimate confines are visible" and "belongs to a most vile category of social fauna; he is a form of human rubbish from the great city" (Ramos 1962, pp. 58-59). For Ramos, the pelado "is an animal whose ferocious pantomimes are designed to terrify others, making them believe that he is stronger than they and more determined" (Ramos 1962, p. 59). In this manner, Ramos sees conflict and violence at the center of Mexican selfhood, leading to his characterization of the pelado as the part-tragic, part-pathetic example of a troubled individualism. Defined by "a constant irritability that incites him to fight with others on the most insignificant pretext", Ramos claims that "the pelado seeks out quarrels as a stimulus, to renew the vigor of his downtrodden ego" (Ramos 1962, p. 59). He continues, "The most destitute of Mexican pelados consoles himself by shouting at everyone that 'he's got balls' (muchos huevos) with reference to the testicles... In the pelado a man who triumphs in any activity, anywhere, owes his success to his 'balls.' Another of his favorite expressions, 'I am your father' (Yo soy tu padre), intends to assert his predominance unequivocally" (Ramos 1962, p. 60). Ramos concludes, "The most striking aspect of Mexican character, at first sight, is distrust" (Ramos 1962, p. 64). Ramos thus invites the troubled early developmental Mexican self in action to the psychoanalyst's clinic. His diagnosis: Mexican selfhood will not soon be attained.

One likely explanation for the unfavorable diagnosis Ramos attributes to the historical and philosophical development of Mexicanidad could be the failure to achieve (or perhaps articulate) an authentic form of national identity. Such a negative psychological disposition as an inferiority complex might be a product of the revolutionary-era rage among Mexico's intelligentsia for all things European. Certainly, this failure is a growing pain that still afflicts searches for Mexicanidad, for imitation of European models rules out authenticity. Speaking to this point, Ramos claims that "Mexicans have been imitating for a long time, without actually realizing that they were imitating" because "they have always sincerely believed that they were bringing civilization into national existence" (Ramos 1962, p. 18). While Ramos implicitly references the work of his predecessors in claiming in this context that "mimesis is an unconscious phenomenon that reveals a peculiar characteristic of mestizo psychology" (Ramos 1962, p. 18), such enduring historical challenges affect the way in which Mexicans and human beings each experience and so conceptualize their sense of self. Mexican history is not the only culprit to blame for the moral failure of achieving Mexicanidad.

Ramos suggests that modernity itself is a culprit responsible for the historical and philosophical challenges preventing the growth and flourishing of Mexicanidad. Ramos turns his focus from the biological origins of Mexican selfhood in Sierra and Vasconcelos to the inner self of psychology. "Modern psychological doctrines teach us that is it impossible to make a man's character intelligible without knowledge of certain childhood experiences definitively influential in the evolution of his soul", he writes (Ramos 1962, p. 30). He adds, "We must therefore go back to the beginnings of our history, to find out whether some event could have projected the evolution of the Mexican soul into a determined orbit" (Ramos 1962, p. 30). In "Psychoanalysis of the Mexican", Ramos asserts, "certain regions of the human soul should remain a mystery, when nothing can be gained by exposing them to the light of day. But it seems harmful for the Mexican to close his eyes to his own character when it works against his destiny; he cannot change his character without first becoming specifically aware of it" (Ramos 1962, p. 55). This feeling or sense of inferiority that for Ramos describes a central problem facing the genuine achievement of Mexicanidad "constitutes a collective illusion which results from measuring man against the very high scales of values corresponding to highly developed countries" (Ramos 1962, p. 57).

Possibilities of transcendence thus face the obstacles of a negative psychology resulting from the historical dominance of European countries over Mexico and Latin America. Co-dependency seems to 
characterize the relationship between Mexico and Europe when seen in terms of the historical problems that still undermine the search for authentic or genuine selfhood. Ramos explains the matter.

The only way open to us-in order to shape this Mexican culture-is to continue learning about European culture...we have not succeeded in forming our own culture, because we have separated culture and life. We no longer want an artificial culture that lives like a hothouse flower; we do not want a false Europeanism. (Ramos 1962, p. 108)

Authenticity becomes an enduring hallmark of twentieth-century Latin American philosophical inquiry. Ramos is explicit: "Just as it should turn away from a universalist type of culture without roots in Mexico, our capital city should reject all picturesque Mexicanism lacking universality. The ideal yet to be achieved, we might say, is personality subjected to a formula which could harmonize the specific values" (Ramos 1962, p. 112). Ramos distinguishes himself as an heir to the fate and question of Mexicanidad. "Up to now", Ramos exhorts, "Mexicans have known only how to die; it is time that they learned how to live" (Ramos 1962, p. 11).

Ramos's focus on youth represents his attempt to negotiate both the uncertain origins and troubled fate of Mexicanidad. Leopoldo Zea summarized the problem.

Our problems, the problem of our thought, of our philosophy, originate in our attempt to maintain two abstractions. The abstractions of a past that we do not consider our own, and the abstraction of a future that is not strange (or foreign) to us. (Zea 1991, p. 288) ${ }^{1}$

For Zea, the process of autoreflexión, or self-reflection, meant that any successful attempt to theorize genuine Mexican selfhood required that a history of colonialism and domination be re-examined. The use of the word authentic or genuine is crucial here. Consistent with the rise of national character studies, and in order to truly break free from European models of the self and modes of thinking, questions of authenticity took center stage. What does it really mean to be Mexican? This was the central question underlying the historical development of Mexican philosophy from 1900-1940, and this question was a central problem for figures like Sierra, Vasconcelos, and Ramos. By the time Octavio Paz entered the discussion under examination, answering the question what does it mean to be Mexican? meant answering how can Mexicans overcome the historical problem of human solitude?

\section{Octavio Paz}

Paz credits Ramos with having genuinely initiated the quest for theorizing Mexicanidad. He writes, "In Mexico, the reflection on these subjects began with Samuel Ramos" who "centered his description around the so-called inferiority complex and what compensated for it: machismo. Although not entirely wrong, his explanation was limited and terribly dependent on Adler's psychological models" (Paz 1985, p. 331). Paz is also critical of Ramos's work in the same chapter of The Labyrinth of Solitude where the reader is first introduced to the pachuco. Paz informs us that he "agreed with Ramos that an inferiority complex influenced our preference for analysis" (Paz 1985, p. 10). However, Paz sees this perspective as limited and excessively psychological in a way that denies the more universal realities of human experience and so the commonalities between Mexicans and all other human beings.

In the same interview, Paz explains that The Labyrinth of Solitude "is part of the attempt of literally marginal countries to regain consciousness: to become subjects again" (Paz 1985, p. 330). Citing Zea's Positivism in Mexico, Paz tells us that he differed from Zea on one key point. Paz shared Zea's general perspective, claiming that Zea's work "is an excellent examination of the historical function of positivism in Mexico and it explains how that philosophy was adopted by the dominant classes"

1 The translation is my own. "Nuestros problemas, el problema de nuestro pensar, de nuestra filosofía, lo ha originado el tratar de mantenernos entre dos abstracciones. La abstraccion de un pasado que no consideramos nuestro, y la abstraccion de un futuro que nos es extrano." 
(Paz 1985, p. 331). Still, Paz criticizes Zea's work for not having recognized that "when positivism crossed the ocean, its nature changed" (Paz 1985, p. 331). The main difference between Zea's work and his own, then, is that Paz believes that "Mexican positivism introduced a certain kind of bad faith in the relations with ideas; an ambiguity not only between social reality and the ideas that pretended to justify it, but also the appearance of a particular type of bad faith, since it was introduced into the very consciousness of Mexican positivists" (Paz 1985, pp. 331-32). Paz then tells us that The Labyrinth of Solitude "is a book of social, political, and psychological criticism", adding, it "tried to be an essay on moral criticism: the description of a hidden reality that hurts" (Paz 1985, p. 332). In this way, Paz retains Ramos's general attitude towards Mexican selfhood as an unhinged and unpredictable self in action.

Paz's analysis of Mexicanidad applies specifically to "those who are conscious of themselves, for reason or another, as Mexican" (Paz 1985, p. 11). As with Sierra, Vasconcelos, and Ramos before him, Paz's treatment of Mexican selfhood necessarily raises questions concerning to the history and so the lived experience of selfhood and circumstances. Three reasons indicate why the pachucos would be a natural beginning for Paz's account of Mexicanidad. First, pachucos are one of the extreme forms Mexicanidad assumes. Second, pachucos live outside of Mexico. Third, pachucos reject both their Mexican and American identity and cultural heritage. "Whether we like it or not", Paz observes, "these persons are Mexicans, are one of the extremes at which the Mexican can arrive" (Paz 1985, p. 14). In at least one sense, Paz's pachuco symbolizes the historical dislocation of Mexican identity. However, if pachucos are a symbol of frustrated or imbalanced selfhood, then they signify more than just a troubled relationship between selfhood and circumstances that the account provided by Ramos suggests.

"A desire for self-abasement", Paz believes, "constitutes the very foundation of his character" (Paz 1985, p. 16). Distinguished by their "singularity", and "unusual erotic prowess", the pachuco is serially described as "the prey of society", "a pariah, a man who belongs nowhere", "someone who ought to be destroyed", and "with whom any contact must be made in secret, in the darkness". (Paz 1985, pp. 16-17). Paz will even go so far as to describe the pachuco as "an impassive and sinister clown whose purpose is to cause terror instead of laughter", (Paz 1985, p. 16). Taken together, these qualities indicate an Existentialist-riddled individual who, in a certain sense, has not figured how to get along in the world. What Paz achieves through this portrait of the pachuco is the claim that the problem of solitude is a fundamental fact of Mexican selfhood. Significantly, Paz's authorial voice in The Labyrinth of Solitude is a first-person narrator, a feature that separates him from Sierra, Vasconcelos, and Ramos. With Paz, the historical and philosophical development of Mexicanidad at last speaks through its own native and personalized voice.

Paz's characterization of pachucos in terms of what he calls their "exasperated will-not-to-be" (Paz 1985, p. 17) explains why the pachuco "denies both the society from which he originated and that of North America" (Paz 1985, p. 17). "When he thrusts himself outward, it is not to unite with what surrounds him but rather to defy it" (Paz 1985, p. 17). Paz's attempt to translate Mexican selfhood (and, more precisely, Mexican solitude) into a model that stands for universal human identity assumes a rather peculiar challenge to European influence over the origin and growth of national character studies in Mexico. To be sure, in characterizing the pachuco in terms of aggression and defiance-or, by what Paz calls "the exasperated will-not-to-be"-Paz relocates the historical and philosophical challenges to Mexican selfhood within the psychology and personal philosophy of Mexican themselves. Further, this characterization re-places the historical and philosophical conflict between European (and north American) thought and Latin American (Mexican) philosophy within the Mexican self. Paz's emphasis on solitude as the defining trait of Mexican selves in action allows him to re-position the terms of his account of Mexicanidad.

Paz distances his own account of Mexicanidad from his compatriots, especially Ramos, by claiming that the solitude of the pachuco "is vaster and profounder than his sense of inferiority" (Paz 1985, p. 19). Paz concludes that his position is incompatible with Ramos because "when you sense that you are alone, it does not mean that you feel inferior, but rather you feel you are different" (Paz 1985, p. 19). 
Paz later amplified this distinction by claiming that "a sense of inferiority may sometimes be an illusion, but solitude is a hard fact. We are truly different ... truly alone" (Paz 1999, p. 19). Paz nonetheless seems to adopt Ramos's psychological portrait of the Mexican pelado given the details of his analysis of the pachuco.

If Paz accepts Ramos's argument, he does so by expanding Ramos's claim that Mexicans suffer from an inferiority complex to now imply a much broader historical development than Ramos seemed concerned to elucidate. According to Paz, "[The Labyrinth of Solitude] has no bearing on Ramos's examination: he dwells on psychology; in my case psychology is but a way of reaching moral and historical criticism" (Paz 1985, p. 332). Just as history was the subject of focus for Vasconcelos, so, too, with Paz who makes explicit what Vasconcelos, at best, implied. Paz observes, "the theme of development is intimately linked with that of our identity: who, what, and how we are. I repeat that we are nothing except a relationship: something that can be defined only as a relationship" (Paz 1985, p. 218). In the plainest statement of Paz's view of Mexicanidad, and to specify the earliest moment and clearest instance where Paz equates Mexican selfhood with universal human identity, he concludes, "The questions of ourselves always turns out to be a question of others" (Paz 1985, p. 218).

Paz re-dresses the Mexican self in existentialist garments of solitude yet distinguishes Mexicans for their authentic, unique, and national sense of personal identity. Paz's peregrination from Mexico and Los Angeles to Paris and Spain thus reverses the direction of thinking on the development of Mexicanidad in Sierra, Vasconcelos, and Ramos to now focus on its migratory nature and trans-Atlantic crossings. After all, Paz wrote The Labyrinth of Solitude while he was working for the Mexican Foreign Service in Paris immediately after the end of World War II. He must have surely been apprised of the carnage and ongoing threats of global warfare. Paz was also in the United States within a few years of the so-called Zoot Suit Riots in June 1943 (See Mazón 1984; Obregón Pagán 2003). The riots were, in fact, precipitated by the unchecked aggression of hundreds of U.S. military servicemen invading the Mexican neighborhoods of East Los Angeles. Teenagers were dragged from movie houses and other public spaces, and were then beaten, bruised, disrobed, and left helpless, naked, and humiliated in street gutters as local police and civic leaders looked the other way.

Zoot suitors were the prototypes for Paz' account of the pachuco. Bringing the central problem of identity (solitude) back home, Paz insists that Mexican nationals are indistinguishable from their pachuco counterparts living in the United States. This double reality for Mexicanidad is, then, problematic for pachucos, proud Mexican nationals, and Europeans equally, all of whom tend to view the Mexican self "as an inscrutable being" who, like the pachuco, "attracts and repels" (Paz 1985, p. 65). "It is not difficult to understand the origins of this attitude toward us", Paz explains. "The European considers Mexico to be a country on the margin of universal history, and everything that is distant from the center of his society strikes him as strange and impenetrable" (Paz 1985, p. 65). A similar relationship is suggested between the United States and Mexico given the violent historical circumstances faced by pachucos. Yet, the pachuco is not Paz's sole concern.

The fact that Paz begins The Labyrinth of Solitude with a philosophical account of the process of self-discovery in adolescents proves his abiding concern with the origins of Mexican selfhood, Mexican solitude, and the universal dimensions of both. "Self-discovery is above all the realization that we are alone", he writes, adding "It is the opening of an impalpable, transparent wall-that of our consciousness-between the world and ourselves" (Paz 1985, p. 9). Since Paz here describes the moment when youths or adolescents first question themselves and their personal identity, he can introduce the problem of solitude by claiming that "The adolescent cannot forget himself ... and we cannot escape the necessity of questioning and contemplating ourselves" (Paz 1985, p. 11). Paz seems to be conscious of the fact that he is crossing political boundaries that have not always existed, and that these boundaries have not always been able to be crossed. "As he leans over the river of his consciousness", Paz continues, "he asks himself if the face that appears there, disfigured by the water, is his own" (Paz 1985, p. 9). Paz started writing The Labyrinth of Solitude the same year as the centennial of the Treaty of Guadalupe Hidalgo. Given the historical relationship between the United 
States and Mexico-a relationship that each of the authors in this work addresses at one point or another-it would seem that the river which reflects this consciousness is none other than the Río Bravo, the Rio Grande.

By composing his analysis of Mexicanidad in France, Paz presents a formidable if not deeply symbolic challenge to European countries whose intellectual yoke has historically overshadowed the productions of Mexican and Latin American thinkers and writers. Again, bona fide Mexicanidad was only possible after the Spanish, French, and American powers were defeated in the 1800s, allowing native national identities to begin to take root and grow by the end of the nineteenth century. Recalling some of the debates that were doubtlessly engaged by members of the Ateneo, Paz's treatment of Mexicanidad again draws on the notion of form. In Paz's words, "Form surrounds us and sets bounds to our privacy, limiting its excesses, curbing it explosions, isolating and preserving it" (Paz 1985, pp. 32-33). Returning to the double irony I have claimed characterizes the twentieth-century development of Mexicanidad, Paz writes, "in a certain sense the history of Mexico, like that of every Mexican, is a struggle between the forms and formulas that have been imposed on us and the explosions with which our individuality avenges itself" (Paz 1985, pp. 32-33). Form implies the notion of a labyrinth, the structure within which all human beings, regardless of national origin, experience solitude.

\section{Conclusions}

In this essay, I argued that the historical and philosophical development of Mexicanidad can be seen as a genealogical problem characterized by a multi-generational search for first principles of national identity. If this is the case, then twentieth-century Mexican philosophical studies on national character were the product of an exceptional and diverse group of individuals who were themselves shaped both by the ideals governing their own generation's thinking and by the larger historical questions each generation faced in terms of what it meant to be Mexican. My essay, for the most part, examined only one or two of the principal works each of these vital figures in the genealogy of Mexicanidad. Admittedly, my threadbare tracing of lo Mexicano in these writings omits so much of their other writings and ideas, even though recent translations and the availability of new texts added to Sierra's and Ramos's accounts above.

But if Paz serves as the final figure in a sequence of four, it is worth noting that while his work has been welcomed in philosophical journals (See Kaiser Ortiz 2012; Hurtado 2016), scholars in disciplines outside philosophy take mixed issue with his treatment of the pachuco. While Luis Alvarez observes neutrally that Paz (among others) "offered widely varying interpretations of the zoot as emblematic of Mexican Americans' cultural struggle to be accepted in U.S. society" (Alvarez 2008, p. 6), Chicano activist David Montejano quotes Paz characterizing Mexican Americans in Los Angeles as clowns, but the quote is taken out of full context and only given negative connotation (Montejano 2010, p. 23). Catherine S. Ramírez nearly denounces Paz. In her words, "According to the cultural critic Octavio Paz, the pachuco had 'lost his whole inheritance: language, religion, customs, beliefs.' In other words, he was a cultural bastard. Even the word pachuco was of 'uncertain derivation' he chided" (Ramírez 2009, p. 3). Ramírez dubs this passage Paz's "less than flattering conclusions" (Ramírez 2009, p. 3). Kathy Peiss strikes a more sanguine tone by claiming that "Paz articulated anxieties that had circulated among Mexican intellectuals and leaders about the nature of national identity and their country's troubling cultural encounters with the United States (Peiss 2011, p. 160). These examples underscore the need for properly locating Paz (and his philosophical forebearers) in a distinct cultural, intellectual, and politico-religious tradition (See Grenier 2002). Paz merits philosophical treatment of his ideas not just on Mexicanidad, but in relation to so many other thinkers and traditions, including the existentialists, surrealists, Latin Americanists, not to mention the influence on his (and others included in this essay) thought India had, as well as the time of his life spent with Maria José.

By the middle twentieth century, Paz was in a unique position to appropriate both the Mexican and the universal experience of solitude given the butchery and devastation of world war, state terror, and casual violence. The similarities and parallels between pachucos in 1940s Los Angeles and post-World 
War II Parisians are one example of where Paz clearly witnessed a connection between Mexicanidad and universal human identity. 1968 and the events at Tlatelolco are another example of this connection (See Kaiser Ortiz 2015). Throughout his lifetime, however, Paz remained fundamentally concerned with universal human identity and the promises of theorizing a philosophy of love in such a way that it would overcome the problem of solitude. This project can be traced, in fact, from the final chapter of The Labyrinth of Solitude, "The Dialectic of Solitude", to one of the last major works before his death, The Double Flame.

The connection between Paz's thoughts on love and his analysis of Mexicanidad, though ultimately beyond the scope of the ideas discussed in this essay, recalls the concerns of Sierra, Ramos, and Vasconcelos for a principle of transcendence that would bring together the place of Mexico with the promise of a universally relevant and natively grown form of national identity. At the end of his chapter in The Labyrinth of Solitude entitled "The Mexican Intelligentsia", Paz describes the sense of what must have been his own sense of the historical and philosophical development of Mexicanidad:

Ever since World War II we have been aware that the self-creation demanded of us by our national realities is no different from that which similar realities are demanding of others. The past has left us orphans, as it has the rest of the planet, and we must join together in inventing our common future. World history has become everyone's task, and our own labyrinth is the labyrinth of all mankind. (Paz 1985, p. 173)

The process of history now becomes the vehicle in which Mexican selfhood travels to universal human identity. As he explains it in Itinerary, "the word history suggests first of all a process, and when you say process you mean quest, usually an unconscious one" (Paz 1999, p. 13). Paz elaborates, "process is quest because it is movement and all movement is a 'going towards'" (Paz 1999, p. 13). Paz then asks, quest (or movement) towards what? (Paz 1999, p. 13). He contends that "the sense of history is ourselves, we who make it and by making it unmake ourselves" (Paz 1999, p. 13). Paz also claims that "man is not only an object or subject of history: he himself is history, he is the changes" (Paz 1999, p. 13). In this way, Paz's theory of Mexicanidad serves as an expression of Mexican national character and universal human identity, both of which are developed at two distinct levels, e.g., the historical process of growth for individuals as well as the process of history that governs the life of generations.

Here, the influence of Paz's predecessors on his treatment of Mexicanidad can be seen as the fourth-generation germinations or flowerings, so to speak, of a natively rooted conception of authentic Mexican selfhood. Recalling Sierra, Paz adds, "this thinking took the shape of a question not only about its origins ... but also on the meaning of the quest that is Mexican history (and everybody else's history)" (Paz 1999, p. 14). In his own remarkably telling words, Paz's describes his young thoughts on matters of selfhood and identity as being "private and collective, mine and everybody's" (Paz 1999, p. 14).

Taking the historical and philosophical development of Mexicanidad one step further, Paz explains that "we are children of that moment in which the different histories of peoples and civilizations flow into universal history" (Paz 1999, p. 14). "More than a vision of world and men", Paz wrote in his biography of Sor Juana, "a civilization is a vision of men in the world and men as a world" (Paz 1988, p. 31). For Paz, then, the self is also part of a larger process involving the social and historical world of others. These relationships are complicated by the fact that we are living for the very first time in a global society. Yet, the problem with selfhood in the twentieth century for Paz is not its origin in national character, but the more universal problem of selfhood devalued and undermined by modern historical circumstances.

Paz's theory of Mexicanidad as it relates to the experience and so the problem of human solitude is a theory that seeks to open the doors of universal human identity in terms of the promise of communion (one form of what I earlier called the principle of transcendence), a process Paz feels is open to all. We, however, all of us-both as unique, individual selves in action and as members of a global 
society-have befallen a periodic crisis Paz calls the "twilight of the idea of the soul" (Paz 1995b, p. 207). This means that "in the sphere of human relations the disappearance of the soul has taken the form of a gradual but irreversible devaluation of the person" (Paz 1995b, p. 207). Paz bemoans modernity, observing that "our tradition told us that every man and woman was a unique, unrepeatable, being;" and yet, the "modern age sees not beings but organs, functions, processes" (Paz 1995b, p. 207). Still, all is not lost, and hope remains. As he wrote in the final chapter of The Labyrinth of Solitude, "during vital and productive epochs, therefore, a mature man suffering from the illness of solitude is always an anomaly. This type of solitary figure is very frequent today and indicates the gravity of our ills" (Paz 1985, p. 204). As a result, the problem of solitude maintains its dual significance in the form of "a break with one world and an attempt to create another" (Paz 1985, p. 204).

Paz offers ample evidence to support this view. He writes, "Society pretends to be an organic whole that lives by and for itself. But ... it is inwardly divided by a dualism which perhaps originated when man ceased to be an animal, when he invented his self, his conscience, and his ethics" (Paz 1985, pp. 201, 204). When these conditions are found lacking, "society lives through a period of crisis: it either explodes or stagnates" (Paz 1985, pp. 201, 204). The main conclusion to be drawn from these experiences, Paz suggests, is "discovering reality as a oneness in which opposites agree" (Paz 1985, p. 202). Ultimately, "love is one of the clearest examples of that double instinct which causes us to dig deeper into our own selves and ... to emerge from ourselves and to realize ourselves in another" (Paz 1985, p. 202). Later, in The Double Flame, Paz writes, "Ever since it appeared on earth, the human being has been incomplete ... almost from the moment of birth, humans flee from themselves", (Paz 1995b, p. 175). "Where do they go? In endless search of themselves. A human being is never what he is but the self he seeks. Once he catches up with himself or believes that he has, again he separates himself, leaves himself behind, continues his pursuit" (Paz 1995b, pp. 175-76). Q.E.D. The historical and philosophical development of Mexicanidad, as articulated by Justo Sierra, José Vasconcelos and Samuel Ramos, up to the work of Octavio Paz, provides a case in point.

Funding: This essay's publication was made possible, in part, by funding from the Faculty Grants Committee of Millersville University.

Conflicts of Interest: The author declares no conflict of interest.

\section{References}

Alvarez, Luis. 2008. The Power of the Zoot: Youth Culture and Resistance during World War II. Berkeley: University of California Press.

Cockcroft, James D. 1968. Intellectual Precursors of the Mexican Revolution, 1900-1913. Austin: University of Texas Press.

Gracia, Jorge J. E., ed. 1986. Latin American Philosophy in the Twentieth Century: Man, Values, and the Search for Identity. Buffalo: Prometheus Books.

Grenier, Yvon. 2002. From Art to Politics: Octavio Paz and the Pursuit of Freedom. Lanham: Rowman \& Littlefield.

Hurtado, Guillermo. 2016. The Labyrinth of Solitude: Construction and Deconstruction. Inter-American Journal of Philosophy 7: 39-55.

Kaiser Ortiz, John. 2012. Octavio Paz and the Universal Problem of Mexican Solitude. APA Newsletter on Hispanic/Latino Issues in Philosophy 11: 1-5.

Kaiser Ortiz, John. 2015. Hazel Barnes and Octavio Paz: Two Existentialist and Pan-American Philosophies of Education. Comparative Philosophy 6: 60-77.

Mazón, Mauricio. 1984. The Zoot Suit Riots; Symbolic Annihilation. Austin: University of Texas Press.

Mendieta, Eduardo, ed. 2003. Latin American Philosophy: Currents, Issues, Debates. Bloomington: Indiana University Press.

Mignolo, Walter. 2005. The Idea of Latin America. New York: Wiley Blackwell.

Montejano, David. 2010. Quixote's Soldiers: A Local History of the Chicano Movement, 1966-1981. Austin: University of Texas Press. 
Obregón Pagán, Eduardo. 2003. Murder at the Sleepy Lagoon: Zoot Suits, Race, and Riot in Wartime L.A. Chapel Hill: University of North Carolina Press.

Paz, Octavio. 1985. The Labyrinth of Solitude. Translated by Lysander Kemp. New York: Grove Press.

Paz, Octavio. 1988. Sor Juana, or The Traps of Faith. Translated by Margaret Sayers Peden. Cambridge: Harvard University Press.

Paz, Octavio. 1995a. In Search of the Present. The Georgia Review 49: 255-64.

Paz, Octavio. 1995b. The Double Flame: Love and Eroticism. Translated by Helen R. Lane. New York: Harcourt Brace \& Co.

Paz, Octavio. 1999. Itinerary: An Intellectual Journey. Translated by Jason Wilson. New York: Harcourt Brace \& Co.

Peiss, Kathy. 2011. Zoot Suit: The Enigmatic Career of an Extreme Style. Philadelphia: University of Pennsylvania Press.

Pitts, Andrea J., Mariana Ortega, and José Medina. 2020. Theories of the Flesh: Latinx and Latin American Feminisms, Transformations, and Resistance. New York: Oxford University Press.

Ramírez, Catherine S. 2009. The Woman in the Zoot Suit: Gender, Nationalism, and the Cultural Politics of Memory. Durham: Duke University Press.

Ramos, Samuel. 1962. Profile of Man and Culture in Mexico. Translated by Peter G. Earle. Austin: University of Texas Press.

Ramos, Samuel. 2017. The History of Philosophy in Mexico (1943). In Mexican Philosophy in the 20th Century. Edited by Carlos Alberto Sánchez and Robert Eli Sanchez Jr. New York: Oxford University Press.

Romanell, Patrick. 1967. The Making of the Mexican Mind. Notre Dame: University of Notre Dame Press.

Sanchez, Robert. 2014. Strengthening the Case for Latin American Philosophy: Beyond Cultural Resources. APA Newsletter on Hispanic/Latino Issues in Philosophy 13: 2-9.

Sánchez, Carlos Alberto. 2016. 20th Century Mexican Philosophy: Features, Themes, Tasks. Inter-American Journal of Philosophy 7: 1-25.

Sánchez, Carlos Alberto, and Robert Eli Sanchez Jr. 2017. Mexican Philosophy in the Twentieth Century: Essential Readings. New York: Oxford University Press.

Sierra, Justo. 1969. The Political Evolution of the Mexican People. Translated by Charles Ramsdell. Austin: University of Texas Press.

Sierra, Justo. 2017. Discourse at the Inauguration of the National University (September 22, 1910). In Mexican Philosophy in the 20th Century. Edited by Carlos Alberto Sánchez and Robert Eli Sanchez Jr. New York: Oxford University Press.

Trejo-Villalobos, Raúl. 2018. Qué es la filosofía? Una introducción a la filosofía mexicana del siglo XX. Inter-American Journal of Philosophy 9. Available online: http://ijp.tamu.edu/blog/?page_id=905 (accessed on 28 May 2020).

Vasconcelos, José. 1926. Aspects of Mexican Civilization: Lectures on the Harris Foundation 1926. Chicago: University of Chicago Press.

Vasconcelos, José. 1997. The Cosmic Race: A Bilingual Edition. Translated by Didier T. Jaen. Baltimore: Johns Hopkins University Press.

Zea, Leopoldo. 1974. Positivism in Mexico. Translated by Josephine H. Schulte. Austin: University of Texas Press.

Zea, Leopoldo. 1991. La Filosofía como Compromiso de Liberación. Prólogo por Arturo Ardao. Caracas. Venezuela: Biblioteca Ayacucho.

(C) 2020 by the author. Licensee MDPI, Basel, Switzerland. This article is an open access article distributed under the terms and conditions of the Creative Commons Attribution (CC BY) license (http://creativecommons.org/licenses/by/4.0/). 